\title{
Rapid and Sensitive Faecal based PCR Assays for the Detection of Parvoviruses in Laboratory Rats
}

\author{
M. R. Srinivasan ${ }^{1}$, K. Vijay ${ }^{2 *}$, S. Ramesh $^{1}$, A.K. Karuppannan ${ }^{2}$ and \\ Y. Krishnamohan Reddy ${ }^{2}$ \\ ${ }^{1}$ Department of Veterinary Pharmacology and Toxicology, Madras Veterinary College, \\ Vepery, Chennai-600007, India \\ ${ }^{2}$ Centre for Animal Health Studies, Tamil Nadu Veterinary and Animal Sciences University, \\ Chennai-600 051, India \\ *Corresponding author
}

\section{A B S T R A C T}

Health status of laboratory rats indicates its suitability for the researches. They are prone to develop viral infections of subclinical nature caused by parvoviruses,

\section{Keywords}

Parvovirus, Fecal PCR assay, Health monitoring

\section{Article Info}

Accepted:

26 July 2020

Available Online:

10 August 2020 which affects the research results adversely; Hence Implementation of health monitoring protocol is essential at the level of breeding colony itself. This study was intended to develop rapid and sensitive fecal-PCR assays to detect infections of multiple species of Parvoviruses affecting rats namely, Rat Minute Virus, Toolan's Parvo Virus, Rat Parvo Virus and Kilham's Rat Virus as an alternate approach to serology based health monitoring in a lab animal breeding unit. All the primers detected only in the presence of the respective templates. PCR assays of RMV and TPV consistently amplified as little as $40 \mathrm{fg}$ and that of RPV and KRV consistently amplified as little as $4 \mathrm{fg}$ of plasmid DNA. Specificity and sensitivity assays indicate that the PCR assays may be useful as diagnostic tools for rapid detection of natural acute viral infections. Further analysis of the primers in the positive laboratory animal colony is essential.

\section{Introduction}

Suitability of laboratory animals for each and every individual research is determined by their health status (Nicklas et al., 1999). The laboratory animals are prone to develop infections caused by various viruses (Elizebath et al., 2012). These pathogens cause infections of subclinical nature, difficult to manage, thus potentially influencing the outcome of the research (Nicklas et al., 1993; Collins and Parker, 1972).

Presence of viruses like Rat parvo virus, Rat minute virus (wan et al., 2006), Toolan's parvo virus and Kilham rat virus (Besselsen et al., 1995a) have been reported to affect the experimental results adversely. 
Presence of infection in laboratory animals can be detected by variety of methods (Fulari et al., 2006). Serological screening provides information about prevalence of infection and microbiological status of laboratory animals (Raut et al., 2007). Common serological method for the detection of prevalence of viral infections in laboratory animals is by using ELISA. However it cannot detect early infection as the induction of antibody response requires 10-14 days post infection, also it cannot be applicable to immunodeficient animals (Wan et al., 2006) and lastly it is prohibitively costly and need to be imported.

PCR assays can detect viruses in early infections prior to serological conversion or in immunocompromised animals that are not capable of developing a serological response (Besselsen et al., 1995a) and PCR assays in fecal samples offer the advantages of easy sample collection and ante-mortem testing of valuable animals (Bauer and Riley 2006).

Hence this study was intended to develop rapid and sensitive fecal based PCR assays to detect active infections of Rat Minute Virus, Toolan's Parvo Virus, Rat Parvo Virus and Kilham's Rat Virusin rats, as an alternate approach to serology based health monitoring in a lab animal breeding unit.

\section{Materials and Methods}

\section{Animal maintenance}

Rats produced and weaned at the site of the present study, the Laboratory Animal Medicine Unit - a breeding unit of Tamil Nadu Veterinary and Animal Sciences University (TANUVAS) were used in this study. This study was carried out after the approval of Institutional Animal Ethical Committee (IAEC), MVC, Chennai-07 (IAEC No. 172/DFBS/B/2013 dated 17.10.2013) and as per the guidelines of the Committee for the Purpose of Control and Supervision of Experimentation in Animals (CPCSEA) Ministry of Environment, Forest and Climate Change, Government of India.

Rats were maintained in polypropylene cages with Corn Cobb bedding material and supplied with ad libdum feed and water. Cages, bedding materials and water bottles were autoclaved and purified water by reverse osmosis method and autoclaved before it was kept in each cage. Animals are maintained at room temperature $22 \pm 3^{\circ} \mathrm{C}$ and relative humidity $50 \pm 10 \%$ and ventilated with centralized air conditioning by HVAC system.

\section{Sample collection}

Fresh fecal samples were collected from the animal cages before blood collection and were subjected to nucleic acid extraction immediately. Fecal samples from the animals of the same cage were pooled before processing.

Blood samples were collected from randomly selected weaned rats. Animals were anaesthetized using 3\% isoflurane using an isoflurane anaesthetic apparatus. Blood samples were collected from anaesthetized rat from the lateral tail vein. Clotted blood samples were centrifuged and the separated serum was stored as aliquots at $-20^{\circ} \mathrm{C}$ used for ELISA.

After blood collection, rats were euthanized by carbon-di-oxide asphyxiation with steady state of increasing the carbon dioxide concentration in the chamber. Mesenteric lymph nodes were collected, for comparison with fecal PCR assays of parvoviruses, in sterile container and stored in $-80{ }^{\circ} \mathrm{C}$ until further use. 


\section{Primers}

Oligonucleotide primers specific for Rat minute virus (RMV) and Toolan's parvo virus (TPV) were designed using NCBI primer designing tool (Table 1). All the gene sequences were obtained from Genbank. Primers were designed based on multiple alignments of target gene (Table 1) sequences using DNASTAR Lasergene software. Primer sequences specific for Rat parvo virus (RPV) and Kilham's rat virus (KRV) were selected as previously published (Table 1). All the primers were synthesized and obtained from sigma.

\section{Viral DNA clones}

Gene templates corresponding with reference gene sequence were synthesised in PUC57 vector for each virus by Genscript. Target gene sequences for all the viral strains were obtained from Genbank and consensus sequence generated, by multiple alignments using DNASTAR Lasergene software, was used for gene template synthesis.

\section{PCR assays}

DNA was isolated from fecal samples of rat. Briefly, one third of single rat fecal pellet was suspended in $2 \mathrm{~mL}$ of sterile Phosphatebuffered saline (PBS), $\mathrm{pH}$ 7.4. The suspension was centrifuged at $700 \mathrm{~g}$ for $5 \mathrm{~min}$ at $4^{\circ} \mathrm{C}$. A $100 \mu \mathrm{L}$ of supernatant of the centrifuged was diluted with PBS at the ratio of $1: 2$ and this fecal mixture was used for DNA extraction (Beckwith et al., 1997). DNA extraction was done from fecal mixture or mesenteric lymph nodes using High Pure Viral Nucleic Acid Kit (Catalogue number. 11858874001) as per the manufacturer's instruction. Purified viral nucleic acids (DNA) were used as template for PCR assays. The DNA content and their purity in the fecal DNA extracts were determined by measuring the A260/A280 optical density ratio with a UV-visible spectrum spectrophotometer.

PCR assays were performed with a final volume of $20 \mu \mathrm{L}$, using $10 \mathrm{pmol}$ in $1 \mu \mathrm{L}$ of each primer, 5ng of template DNA, $10 \mu \mathrm{L}$ of ready to use Taq DNA polymerase $2 \mathrm{X}$ master mix red (AMPLIQON, Denmark) and the final volume was adjusted with nuclease free water. All PCR assays included positive and negative controls. An initial denaturation step of $95^{\circ} \mathrm{C}$ for $3 \mathrm{~min}$ followed by 40 cycles of denaturation at $95^{\circ} \mathrm{C}$ for $45 \mathrm{sec}$, annealing (Table 1) for $20 \mathrm{sec}$ and extension at $72^{\circ} \mathrm{C}$ for $1 \mathrm{~min}$ and a final extension at $72^{\circ} \mathrm{C}$ for $7 \mathrm{~min}$. Amplicons obtained from PCR reactions were subjected to electrophoresis on a $2 \%$ agarose gel. Ethidium bromide $(10 \mathrm{mg} / \mathrm{mL})$ was added at $5 \mu \mathrm{L} / 100 \mathrm{~mL}$ just before casting gel. Amplicon size was compared with molecular weight markers and visualized in Bio-Rad gel documentation system

To assess the sensitivity of the PCR assay, 1 $\mu \mathrm{L}$ of quantified purified plasmid vector in 10 fold serial dilutions (figures) were used as template for PCR assay. To mimic diagnostic samples $5 \mathrm{ng}$ of rat fecal DNA (Negative for parvovirus DNA) were added to the PCR assays. In the absence of positive samples for the Parvoviruses included in the study, specificity of each virus was analysed using plasmid DNA of all other viruses included in the study.

\section{Serology}

Serum samples were analyzed by Sandwich ELISA using the available commercial kits (XpressBio Life Science Products, Thurmont, MD 21788, USA), for the presence or absence of antibody as per the protocol described by manufacturer. 32 samples from Wistar rats were screened for antibody against viral pathogens namely RPV and KRV. 


\section{Results and Discussion}

On comparison of the nucleotide sequences after multiple alignment of VP2 segment of RMV and TPV with those of other rodent parvoviruses, showed limited homology. Primers specific for strains of RMV and TPV were designed to provide maximum heterology with aligned region of other rodent parvoviruses. In addition to designing of primers showing maximum heterology, the nucleotide in the 3'-end of either or both primer were designed as a mismatch base in the sequences of the other related viruses for improving its specificity.

Sensitivity of each virus was determined by using 10 fold serial dilution of plasmid containing gene sequence of each virus along with rat fecal DNA added at the concentration of $5 \mathrm{ng}$ per assay (Negative for all viruses). Concentrations of plasmid DNA ranged from $400 \mathrm{pg}$ to $4 \mathrm{fg} / \mathrm{PCR}$ assay were used. PCR assays of RMV and TPV consistently amplified as little as $40 \mathrm{fg}$ and PCR assays of RPV and KRV consistently amplified as little as $4 \mathrm{fg}$ (Figure 1) of plasmid DNA in the presence of negative control fecal DNA.

Previously published PCR assays for prototypic Parvo viruses detected as low as $100 \mathrm{fg}$ of DNA of TPV, $10 \mathrm{pg}$ of DNA KRV (Besselsen et al., 1995a and 1995b), $0.092 \mathrm{fg}$ of DNA of RPV, $0.18 \mathrm{fg}$ of DNA of RMV-1 (Wan et al., 2006). All the studies varied with, usage of DNA purified from viral culture, cell culture stocks or plasmid DNA as template, detecting sensitivity in the presence of tissue DNA or fecal DNA.

Table.1 Oligonucleotide primers used and gene targeted for viruses of rats

\begin{tabular}{|c|c|l|c|c|}
\hline Virus & $\begin{array}{l}\text { Target } \\
\text { Gene }\end{array}$ & Sequence (5'-3') & $\begin{array}{l}\text { Product } \\
\text { size }\end{array}$ & $\begin{array}{l}\text { Annealing } \\
\text { temperature }\end{array}$ \\
\hline $\begin{array}{c}\text { KRV } \\
\text { (Besselsenet al., 1995a) }\end{array}$ & VP1 & $\begin{array}{l}\text { GCACAGACAACCAAACAGGAA } \\
\text { CTCTCC } \\
\text { AGTCTCACTTTGAGCGGCTG }\end{array}$ & $281 \mathrm{bp}$ & $64^{\circ} \mathrm{C}$ \\
\hline $\mathbf{R M V}$ & VP2 & $\begin{array}{l}\text { ACCAAACGGACTAAACTCTCA } \\
\text { TTGAGTTCAGGTTTGGTGGA }\end{array}$ & $566 \mathrm{bp}$ & $57^{\circ} \mathrm{C}$ \\
\hline $\begin{array}{c}\text { RPV } \\
(\text { Wan } \boldsymbol{e t} \text { al., 2006) }\end{array}$ & NS1 & $\begin{array}{l}\text { CGCACATGTAGAATTTTGCTG } \\
\text { CAAAGTCACCAGGCAATGTGTT }\end{array}$ & $486 \mathrm{bp}$ & $58^{\circ} \mathrm{C}$ \\
\hline $\mathbf{T P V}$ & VP2 & $\begin{array}{l}\text { ATTACTCTCCTGCGCACA } \\
\text { GGTTTGGTTTGGTGGA }\end{array}$ & $517 \mathrm{bp}$ & $62^{\circ} \mathrm{C}$ \\
\hline
\end{tabular}

Table.2 Prevalence of viral infections in Rat by ELISA and PCR

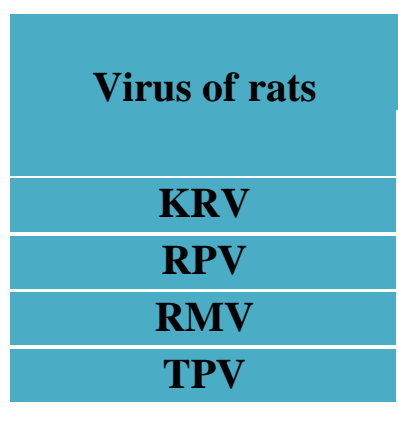

\begin{tabular}{|c|c|c|c|}
\hline \multicolumn{2}{|c|}{$\begin{array}{c}\text { PCR assay (Fecal samples } \\
\text { and mesenteric lymph node) }\end{array}$} & \multicolumn{2}{|c|}{ Serology } \\
\hline Positive & $\%$ incidence & Positive & $\%$ incidence \\
\hline $0 / 32$ & 0.00 & $0 / 32$ & 0.00 \\
\hline $0 / 32$ & 0.00 & $0 / 32$ & 0.00 \\
\hline $0 / 32$ & 0.00 & - & - \\
\hline $0 / 32$ & 0.00 & - & - \\
\hline
\end{tabular}


Figure.1 Ethidium bromide stained gel showing detection of sensitivity of PCR assay (A) TPV, (B) KRV, (C) RMV and (D) RPV in fecal samples. M- marker,6- 400pg, 5- 40pg, 4- 4pg, 3400fg, 2-40fg, 1-4fg of positive plasmid DNA template with fecal DNA

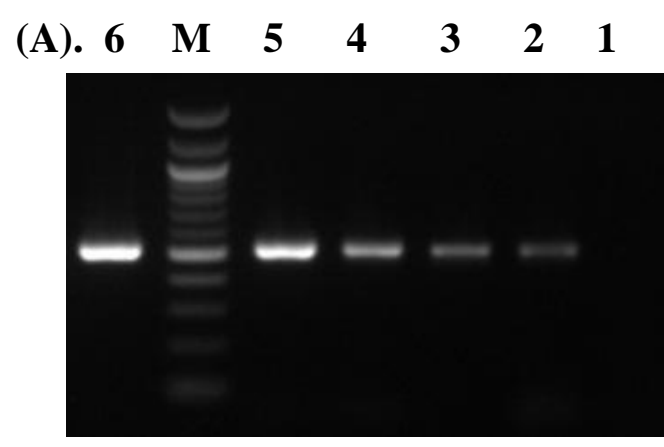
(B). 1

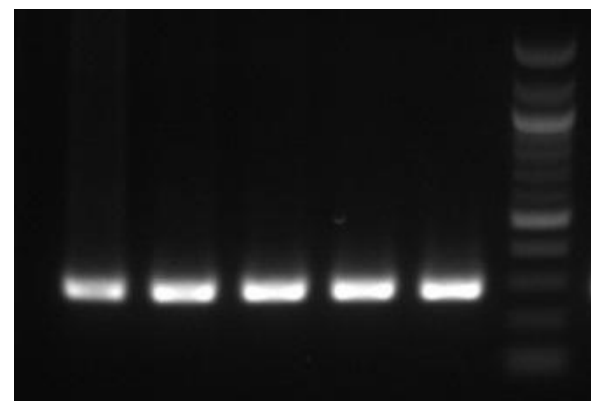

(C). M $\begin{array}{lllllll} & 6 & 5 & 4 & 3 & 2 & 1\end{array}$

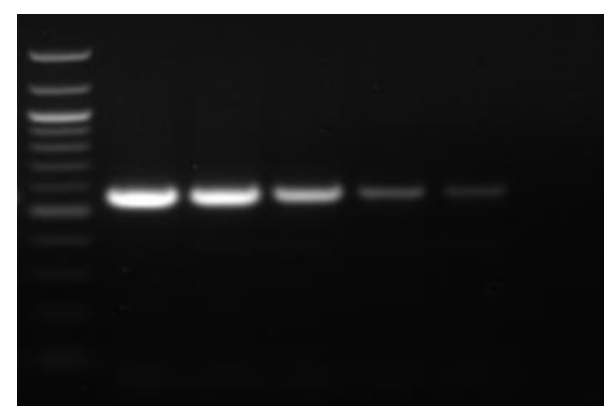

(D). $\begin{array}{llllll}M & 5 & 4 & 3 & 2 & 1\end{array}$

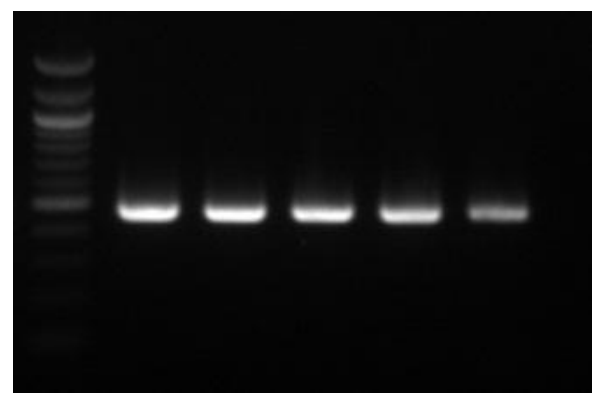

486bp 566bp 
In the current study, Plasmid DNA was used for the detection of sensitivity of each set of primers, hence sensitivity assay for all the viruses were limited to $4 \mathrm{fg}$ of Plasmid DNA, to avoid over-estimating the efficiency of primers when it is used for detecting the viral DNA in natural infection in fecal samples.

Primers of KRV, TPV, RMV and RPV specifically detected the viruses in the presence of respective DNA templates and not in the presence of other DNA templates.

Serological results and PCR assays (Table 2) in the fecal samples as well as mesenteric lymph nodes showed that the parvo viruses were not prevalent in the rat colony and the absence of infection is the reason for negative results of PCR in rat fecal samples.

In conclusion, PCR assays were developed for the set of parvoviruses infecting rats, included in the study. The fecal based PCR assay is a sensitive method and detects at least $40 \mathrm{fg}$ of DNA (viruses included in the study) in fecal samples. The results of the specificity and sensitivity indicate that the fecal-PCR assays may be useful as non-invasive diagnostic tools for rapid detection of natural acute parvovirus infections. Further analysis of the primers in the positive laboratory animal colony is essential.

\section{Acknowledgement}

This work was funded by SERB, DST, Government of India. Thanks to the Directorate of Centre for Animal Health Studies, TANUVAS for the laboratory space and expert guidance for the conduct of the study.

\section{References}

Bauer, BA., and Riley, LK. 2006. Antemortem detection of mouse parvovirus and mice minute virus by polymerase chain reaction (PCR) of fecal samples. Lab Anim. 40, 144-152.

Beckwith, CS., Franklin, CL., Hook, RR., Besch-willford, CL., and Riley, LK. 1997. Fecal PCR assay for diagnosis of Helicobacter infection in laboratory rodents. J Clin Microbiol. 35(6), 16201623.

Besselsen, DG., Besch-Willford, CL., Pintel, DJ., Franklin, CL., Hook, RR., and Riley, LK. 1995a. Detection of H-1 Parvovirus and Kilham Rat Virus by PCR. J Clin Microbiol. 33(7), 16991703.

Besselsen, DG., Besch-Williford, CL., Pintel, DJ., Franklin, CL., Hook, RR., and Riley, LK.1995b. Detection of Newly Recognized Rodent Parvoviruses by PCR. J Clin Microbiol. 33(11), 28592863.

Collins, MJ., and Parker, JC. 1972. Murine virus contamination of leukemia viruses and transplantable tumors. J Natl Cancer Inst. 49, 1139-1143.

Elizabeth, FM., Rasmussen, L., Fung, P., Amanda, MA., Luisana, A., David, AL., Morgan, EQ., Tammy, DD., Gloria, MDF., and Bianca, AV. 2012. Prevalence of viral, bacterial and parasitological diseases in rats and mice used in research environments in Australia over a5-y period.Lab Animal Asia Pacific. 3, 4-14.

Fulari, SN., Nipunage, SV., and Raut, CG. 2006. Seroprevalence of natural pathogens of laboratory animals" Abstract Book: First National Conference on "Rational use of Animals in Research, organized by NIN, LASA and IPS, Hyderabad, P45.

Nicklas, W., Homberger, FR., Brunhilde, IW., Jacobi, K., Kraft, V., and Kunstyr, I. 1999. Implications of infectious agents on results of animal experiment. Lab Anim. 33(1), 39-87. 
Nicklas, W., Kraft, V., and Meyer, B. 1993. Contamination of transplantable tumors, cell lines and monoclonal antibodies with rodent viruses. Lab Anim Sci. 43(4), 296-300.

Raut, CG., Gengaje, BB., Fulari, SN., Nipunage, SV., Waghmare, SB., and Zaheer, SM. 2007. Bacteriological assessment of conventional and barrier housing systems used for laboratory mice. Abstract Book-2nd National Conference on Current Perspectives and Future Challenges in Laboratory Animal Management, IISc, Bangalore, p44.

Wan, CH., Bauer, BA., Pintel, DJ., Riley, LK. 2006. Detection of rat parvovirus type 1 and rat minute virus type 1 by polymerase chain reaction. Lab Anim. 40(1), 63-69.

\section{How to cite this article:}

Srinivasan, M.R., K. Vijay, S. Ramesh, A.K. Karuppannan and Krishnamohan Reddy, Y. 2020. Rapid and Sensitive Fecal based PCR Assays for the Detection of Parvoviruses in Laboratory Rats. Int.J.Curr.Microbiol.App.Sci. 9(08): 3506-3512.

doi: https://doi.org/10.20546/ijcmas.2020.908.405 